\title{
Bodies, Bare Life and Dehumanisation in the My Lai Massacre
}

\author{
Rebecca Russell
}

\section{Abstract}

Since the end of the Vietnam War, the conflict has held a troubled place within the Australian, American and Vietnamese public memory, due to the allegations of misconduct by troops of these militaries. The 1968 My Lai Massacre is the largest isolated war crime performed by Western forces, and yet is an event that has lacked serious analysis from anthropologists. By analysing the events of that day as recounted by the participants and the underlying cultural constructs of the American military through the framework presented in Agamben's Homo Sacer, a greater appreciation of the cultural factors that contributed to the My Lai Massacre can be reached. The Massacre is here understood as an attempt by the soldiers to make sense of the war landscape, by enacting destruction on the bodies of civilians to echo and reaffirm the damage on the Vietnamese states. By understanding the Massacre and the events that followed, steps can be taken to ensure that it is not repeated in contemporary and future wars.

\section{'This was a moment of evil... we would never live the same'1}

The name of My Lai has become shorthand for the worst excesses of soldiers' behaviour within war, and the failures of the United States military to not only prevent, but also effectively address, such wartime atrocities. The four hours of the morning of 16 March 1968 in the village of Son $\mathrm{My}^{2}$ in which hundreds of South Vietnamese civilians were assaulted, raped and murdered by members of the Task Force Barker consisting of 'B 'Bravo' and C 'Charlie' Companies, have become one of the most studied, discussed and contested events in recent history (Oliver, 2006: 2-3). The crimes of that morning have left an indelible stain on the memory of the Vietnam War (1962-1975). As with other crimes

1 Heinemann, 1984: 184.

2 The confusion over the name of the village reveals the difficulty with which the American troops had understanding the Vietnamese. The Massacre occurred in the hamlets of Son My (Xom Lang) and My Khe in the Tu Cong village, Tinh Khe commune, Son Tinh district in the Quang Ngai province (Oliver, 2006: viii). 
committed by militaries, the My Lai Massacre has been dismissed by supporters of the soldiers as the inevitable cost of the type of war in Vietnam (Oliver, 2006: 9), while others viewed it as the inevitable result of the militarisation of young men (Enloe, 2004). The military hierarchy and the Nixon administration presented it as an isolated event (Oliver, 2006: 9). I argue that the explanations forwarded previously are inadequate for understanding the dehumanising acts of soldiers against each other and civilians during wars. Rather than viewing war crimes as isolated acts that occur as a result of a perfect storm of conditions and individuals, I argue that a consideration of such acts of a continuum of war crimes offers a richer analysis, as a legacy of brutality and dehumanisation can then be considered. Such a legacy results from cross-cultural flows between belligerents and institutions, founded upon the national myths, histories and constructs of nationhood. By understanding how the conceptual tools that allow soldiers to commit war crimes are constructed, communicated and renegotiated in these broader social and temporal contexts, we are able to more fully understand how these crimes are perpetrated or avoided by combat troops in a war zone. While there are numerous examples of war crimes performed by 'Western' forces during modern conflicts, this article will focus on the My Lai Massacre: the most controversial, well known and well documented war crime to occur during the Vietnam War. It is an ideal site for the investigation of competing cultural norms, history and identity due to its relatively recent occurrence, the nature of the warfare and the lasting impact it has had upon the collective consciousness and imagination in Australia, the United States and Vietnam. Although circumstances and factors may change, the experiences of this War can influence how we understand soldiers and may go some way to the elimination of these atrocities in the present and the future.

The twentieth and twenty first centuries have witnessed an unprecedented capacity of states, militaries and militias to inflict devastating damage on infrastructure, the environment and enemy peoples (Bourke, 1999: 6). The creation of chemical, biological and nuclear weapons of mass destruction, and the greater involvement of civilian populations in armed movements have resulted in a military landscape that appears radically different to that of the early part of the twentieth century. Nonetheless, wars have not changed their complicated relationship to those who take part in them, giving rise to highly complex positive and negative experiences ranging from friendship and creative expression, to death and destruction (Bourke, 1999: 1-2). There is no singular war experience as every participant fights their own war, yet common elements can be identified in the causes and conduct of conflict. In addition to wars of political control over territories, conflicts post-WWII have increasingly seen the incorporation of resource and identity politics as causes for the legitimate use of force. For the West, major wars have traditionally been fought conventionally, involving large regular armies on clearly demarcated battlefields, such as the 
First and Second World Wars (Kilcullen, 2010: ix-x). However, since the Vietnam War, guerrilla and counter-insurgency conflicts have become the regular pattern of warfare (Kilcullen, 2010: ix-x). Kaldor termed the post-WWII conflicts as 'new wars', in which 'territory is captured through political control of population rather than through military advance, and battles are to be avoided as far as possible' (2006: 8). For Kaldor, the process of globalisation is one of the key elements in the 'new war' paradigm, as there are transnational flows of people, arms and information, in addition to the destabilisation of the notion of the nation-state (2006: 4-5). While the physical body has always been important to war, the site of this importance has shifted. Instead of the nation-state only being held in the bodies of soldiers, it is now held in the bodies of the citizens of the state, who have become the state on the basis of identity politics (2006: 7-8). In contrast with previous conflicts, some $60-80 \%$ of all conflict casualties are now civilians, a reflection of the new state of combat culture and political and military realities (Giles and Hyndman, 2004: 5). ${ }^{3}$ The proliferation of small arms and utilisation of terror methods has eroded the distinction between soldier and civilian, as it is now easier for civilians to engage in combat without being members of a regular military. This identification of the bodies of civilians as the state means that to attack the nation-state most effectively, the bodies of civilians are legitimate targets for violence. The military and political cultures contribute to the ability of military and political regimes to hold the imagination, loyalty or fear of the population, and thus control the access to resources and land that are essential to determining the victor. The narratives which inform these beliefs often do not apply to these new wars, leaving combatants confused and disoriented, trying to position themselves and their actions as righteous, while often receiving messages that these wars are not 'true' wars, or lack the honour of those that had come before.

In order for combatants to engage with an enemy, and cause injury, death and destruction, service-personnel need to be able to view those that they are fighting as a foreign 'other', whose culture, values and very existence are alien to their own, thus enabling and justifying their destruction (Lifton, 1972: 4243). Within the landscape of new wars, actors move in fluid and dynamic ways, often changing allegiances or acting in ways to secure their own allegiances and survival. Contrasted with their predecessors, service-personnel postWWII contend with a civilian population that they are unsure of: even small children and women, previously 'protected' from active engagement in fighting in conventional wars, may now be recognised as sympathisers or combatants (Kilcullen, 2010: 40). Indeed, the 'enemy' itself no longer holds an easily

3 While this number has been questioned, the statistics from the Vietnam War indicate the swing towards high civilian casualties. Civilian casualties are estimated to be over 1,100,000 including some 300,000 dead; while in contrast, the Australian Defence Force lost 521 out of 3,500 casualties (Ham, 2008: 400 and Australian War Memorial, n.d.a). 
identifiable body, as they may be members of the state, but also foreigners engaging in combat for the cause (Kilcullen, 2010: 30), and lack the uniform, structure and equipment that identify regular military personnel. As such, postmodern wars are difficult to fight, and even more difficult to win as the opposition retains home ground advantage over the local environment, culture and language (Kilcullen, 2010: 11-12). It is this aspect of uncertainty about who is the 'enemy' that has led to events such as the My Lai Massacre, as troops are faced with social constructs that they have no understanding of, in a population they can perceive to be entirely hostile. The othering processes of military doctrine, while always deadly, have taken on new aspects, as service-personnel struggle to place themselves in the new frontier of organised, legitimated violence.

I argue here that war crimes are not isolated acts; rather, they are a product of the othering processes that have their roots in the constructions of 'hostile' and 'friendly' bodies. These bodies are constructed on social, political and national levels, informing the constructions of and responses to the 'enemy' by individual soldiers, often in retaliation for the acts committed by the other side. These constructions are particular to nations, and so I do not present a universal explanation for war crimes. Wars are products of their environment, and fought and won by the troops who bring their ideological and cultural backgrounds into the battle.

\section{‘My nation thought my body belonged to it' ${ }^{4}$}

In Homo Sacer: Sovereign Power and Bare Life (1998), Giorgio Agamben discusses the operation of power by state sovereignty and the crisis of the modern. Key to his conceptualisation of these issues is zoë and bios, two terms borrowed from classical Greek political thought. Zoë is 'the simplest fact of living common to all living beings', while bios is 'the form or way of living proper to an individual or group' (Agamben, 1998: 1). Bare life is the evolution of zoë within the frame of sovereign power, and is that which is outright the rights of citizenship, but inside what is included in citizenship (Dennis and Warin, 2010: 52). Unlike bare life, bios retains its power as that of privileged life, subject to biopower but also enjoying its protection. Through this exercise of sovereign power, bare life is separated from bios, becoming life 'that can be killed, but not sacrificed' (Dennis and Warin, 2010: 52). These categories are deployed through three principles which are central to Agamben's work. The first is the ban, the 'original political relation' in which the ban or state of exception is a zone of indistinction between 'outside and inside, exclusion and inclusion' (Laclau, 2007: 12). It is

4 Hans, 2004: 245 
this ban, which allows the sovereign to control those who are constitutive of it, that then gives rise to the second thesis, where 'the fundamental activity of sovereign power is the production of bare life and originary political elements and as threshold of articulation between nature and culture, between zoë and bios' (Laclau, 2007: 12). The distinction between the above kinds of life, and the sovereign power to designate and then control people on the basis of this difference gives rise to the final thesis, in which 'the camp', rather than 'the city' has become the 'fundamental biopolitical paradigm of the West' (Laclau, 2007: 12).

Agamben's work allows us to appreciate the justification for targeting civilian bodies in war. As new enemies are created through the shifting landscape of postmodern wars, new populations are available to be included or excluded from bios and placed within a framework of acceptable and legitimate death. To recognise the 'other' as possessing bios is to recognise them as fully human, and thus unavailable for killing: to designate them as only possessing bare life means they are dehumanised and minimised, and able to be killed in the pursuit of the goals of the state. Soldiers may be sacrificed for the nation-state during a war, and indeed, war is dependent upon this sacrifice of young men and women in the name of their nation-state. The citizens of other states within a conflict zone have bare life, and so are available for killing by the soldiers of their enemy. The deaths of soldiers are seen differently, due to the function of the soldier to be available for death, while still retaining the bios of the citizen. Formulated in this way, the deaths of civilians are no longer considered a crime, as those who hold only bare life are outside of the state, although their bodies represent and hold the state to those around them. Agamben's interest in the crisis of the modern, and the value applied to different categories of life within the state allow for an understanding of militaries do this in order to operate most effectively to combat their enemy within a war zone.

\section{'Induction, then destruction' ${ }^{5}$}

The Vietnam War has retained an important place within the collective imaginations of Australians, Americans and the Vietnamese. With unprecedented ability to capture, transmit and broadcast film and photographs, journalism defined the War for Australians and Americans and served a key role in ending the conflict. At the same time, the War has been depicted in a variety of popular culture, including protest songs, memoirs, film and fiction. ${ }^{6}$ Due to the long duration of the War, and the impact of social movements, including civil rights, feminism, anti-communism and counter-culture, no culture product can be

5 Starr, [1970] 1998: 292.

6 Notable examples include Fortunate Son (1969), Born on the Fourth of July (1976), Apocalypse Now (1979) and Paco's Story (1984). 
representative of the War, although they have been absorbed and represented as such. By understanding the Vietnam War through these products, a conversation around the place of and responsibility to the ghosts of the dead and the survivors can be avoided. ${ }^{7}$

Australia's involvement in the Vietnam War lasted from 24 May 1961, until April 25, 1975 (Caulfield, 2007: 64-65 and Ham, 2007: 598). ${ }^{8}$ It began with the deployment of a group of 30 military advisers following the end of French colonialism, in an attempt to stop the growing influence of Communism in South-East Asia (Caulfield, 2007: 64-65). The commitment of troops escalated quickly, and in 1965 both President Lyndon Johnson and PM Robert Menzies had sent soldiers (Caulfield, 2007: 146). These troops faced two different Vietnamese forces: the North Vietnamese Army (NVA), a conventional army, and the National Front for the Liberation of South Vietnam (NFL or NLF), or the Viet Cong (VC) the guerrilla force in the South (Caulfield, 2007: 76-77). ${ }^{9}$ While a military failure, the Tet Offensive over the cease-fire period of the Lunar New Year in 1968 convinced much of the Australian and American publics that it was unwinnable, leading to mass public protests and widespread dodging of the conscription draft (Caulfield, 2007: 365-376). Faced with the unpopular War that seemed to have no clear end, Australia and the United States began to plan their withdrawal (Ham, 2007: 551). Active duty soldiers were pulled out, giving way to the NVA (Ham, 2007: 551-552). Australia's official involvement ended in 1973, leaving behind military advisers and the embassy security detail (Ham, 2007: 552). The United States began the process of 'Vietnamisation', pushing the Southern forces forward to cover their retreat (Ekberg, Forman, Nyhammer, Maievskij, Rossdale, 1972: 104). On April 25, 1975 the Australian personnel pulled out of Saigon (Ham, 2007: 598), followed by the Americans on the 30th (Ham, 2007: 603). With the fall of Saigon, the Vietnam War was finally over. The legacy of the War, however, was only just beginning to be written.

\footnotetext{
7 In The Remnants of Auschwitz, Agamben considers the place of the 'survivor' through the figure of the Muselmann (Muslim) in the Holocaust. Taking this idea from the meaning of the word Muslim, which is 'one who submits to God', the Muselmann submitted to the conditions of the camp having given up the hope to survive an unchanged person. In their submission the Muselmann 'marked the moving threshold in which man passed into non-man' (Agamben, 1999: 47). Those who submitted were not the survivors, but rather the real and only witnesses: the extreme nature of the situation means that only the dead can bear witness. Survivors can claim only to testify in their stead. Those who are going to be able to bear witness in the future, the true witnesses, are those who straddle the threshold between inhuman and human: homo sacer, the walking dead and finally the actual dead.

8 For a more comprehensive overview of the involvement of Australia in the Vietnam War see Ham, 2007; Caulfield, 2007 and Australian War Memorial, n.d.b.

9 The nickname Viet Cong was given by Southern President Ngo Dinh Diem, shortened from Vietnamese Communists (Caulfield, 2007: 77). Intended to denigrate them, it was proudly claimed by its members (Caulfield, 2007: 77).
} 


\section{'The devil's butcher shop'10}

At around 7 a.m. on the morning of March 16, 1968, an artillery barrage battered the village of My Lai (Cotkin, 2010: 42). About 20 minutes later, nine helicopters carrying three American infantry platoons landed near a rice paddy (Cotkin, 2010: 42). The men, members of Task Force Barker (Oliver, 2006: 1) were expecting a fight with battle hardened NVA and VC members (Cotkin, 2010: 42). In a briefing the previous evening, C Company's commanding officer Captain Ernest Medina had asserted that there would only be VC in the village, as the civilians would be at the market in the morning (Cotkin, 2010: 42). Afterwards, the members of the unit had different recollections of his speech, with interpretations varying from destruction of property to the deaths of all inhabitants (Cotkin, 2010: 42 \& 96). Entering the village, the men encountered no enemy forces or resistance of any kind (Cotkin, 2010: 78), instead finding hundreds of civilians, including old men and young children (Oliver, 2006: 1). By lunchtime, the people of My Lai and My Khe had been murdered, raped, tortured and mutilated, as their homes and crops were burned, wells poisoned, and animals killed (Bourke, 1999: 172). Lieutenant William Calley, the only soldier to be tried and sentenced for the killings, was found during the trial to have led much of the killing, pressuring other men to kill (O'Brien, 1998: 669670). The only intervention came from Warrant Officer Hugh Thompson and his helicopter crew (Barnett, 2010: 207). Thompson and his crew rescued a number of civilians, and reported the actions of Task Force Barker to superiors on base (Barnett, 2010: 207-208). These superiors were 'apprised of possible mass killings of non-combatants, but all either failed to act or acted deliberately to conceal the crime' (Barnett, 2010: 209). After his discharge, unit photographer Ron Haeberle sold his personal photographs taken on the day to Life magazine, leading to widespread outrage about the Massacre (Oliver, 2006: 21). In 1970, Lieutenant General William R. Peers led an investigation into the incident, verifying the killings, and confirming that the military leadership had failed from Lt. Calley to the highest ranks of the US military, none of whom had acted to prevent, or then address the illegal actions against the civilians (Barnett, 2010: 209). The Peers Commission led to the 1970 trials of 14 commissioned officers involved in the massacre, although 13 of the men had their charges dismissed, leaving Calley as the only participant to be charged, tried and sentenced (Barnett, 2010: 211). Under public pressure, Calley's sentence of life at hard labour was reduced until he was finally freed by Presidential order in 1975 (Bourke, 1999: 173).

The public reception within the United States to the My Lai Massacre was mixed. The publication of Haeberle's photographs was used to boost the burgeoning anti-War movement (Oliver, 2006: 101). For members of the public, however,

10 Cotkin, 2010: 78 
the actions of Task Force Barker were understandable. Calley had become a folk hero, representative of all those young men who were returning from the War physically and mentally injured (Barnett, 2010: 227). While awaiting trial, he received 'marriage proposals, was deluged with friendly invitations and valuable gifts... and asked to sign autographs' (Barnett, 2010: 205). People expressed sympathy for Calley and the other killers, suggesting that the blame for My Lai belonged with the American military and state more than with the men who had committed the killings (Barnett, 2010: 227).

\section{'What are we fighting for?'11}

The Peers Commission revealed systematic failures in dealing with the My Lai Massacre. What it did not reveal however, was why these acts had occurred, or the numerous smaller acts of wartime atrocities that had been committed in the name of the American nation-state. While American perpetration of war crimes was shocking, it could be excused: Calley's supporters blamed the military, not him, for the Massacre. The responsibility of the individuals, and the responsibility of the American nation-state were absent from the discussion.

Within conflicts, the distinction between bare life and bios had previously been applied to the population of the opposing state: soldiers could be killed, or sacrificed, in the name of the state, while civilians were not to be killed, and if they were, their deaths held a different, more tragic meaning to that of the soldier's. During the Vietnam War, VC militia relied heavily on the participation and support of civilian men, women and children, who would supply intelligence, materials and often participate in attacks. For the men of Task Force Barker, this was a challenging landscape. The soldiers found themselves moving within a challenging landscape akin to that of the men in Roger Casement's Putumayo Report in Taussig's Culture of Terror-Space of Death (1984). They were in a self-constructed space of death where 'the social imagination had populated its metamorphosing images of evil and the underworld' (Taussig, 1984: 468). The reality of the Vietnamese possessing individual physical bodies and bios was ignored. As a mysterious population with alien bodies, the Vietnamese were distanced from the American and Australian soldiers through culture, ethnicity, politics and language. In Taussig's formulation, 'the victimiser needs the victim for the purpose of making truth, objectifying the victimiser's fantasies in the discourse of the other' (1984: 469). The Vietnamese civilians were less important through their physical reality than the purposes served by their social and

11 McDonald, [1965] 1998: 286. 
political aspects. Justifying the murders of children and women through their potential to act as combatants, the men of Task Force Barker became like the men in the Casement Report:

They saw everywhere attacks by Indians, conspiracies, uprisings, treachery etc.; and in order to save themselves from these fancied perils... they killed, and after work was over, these stories and the imagination they sustained were potent political forces without the work of conquest... could not have been accomplished (Taussig, 1984: 492).

Stories of the War circulated amongst the troops on the ground, and filtered back to those in training in the US. Arriving in Vietnam, troops found themselves trapped in a landscape of thick jungles, inscrutable locals and a military hierarchy that depended on one's ability to dehumanise their enemy. In these circumstances, the My Lai Massacre serves to reinforce the ability of civilians in Vietnam to act as combatants, while also reinforcing their lack of value within the War. Bravo and Charlie Companies acted as agents of the political body that they had come from, primed by a military that could not accept the bios of others. Both Companies were made up mainly of conscripted troops (Barnett, 2010: 222). Unwilling or unable to seek an exemption from service, they had gone to Vietnam carrying national myths of power and righteousness of the American state (Hellman, 1997: 177). The men of Charlie Company had formed extraordinarily close bonds whilst training in Hawaii, which enabled them to ensure the difficult conditions in the jungle, however deaths of unit members had left them angry and confused (Bourke, 1999: 203-204). Participants are reported to have referred to this during the Massacre, shouting 'that's for Bill Weber', 'VC bastards, you dirty VC bastards' and 'cry, you gook bastards, cry like you made us cry' as they killed (Lifton, 1973: 51-52). Even the killing of the smallest infants was justified: 'they'll grow up [to help the VC]' (Lifton, 1973: 56). In the absence of an enemy they could touch, the soldiers at My Lai and throughout Vietnam instead attacked the civilians who represented the Communists. Through their bodies, the civilians no longer had the bios expected during peace. The circumstances of the War, the conditioning of the men and their confusion about the combat status of the civilians allowed some of the men of Task Force Barker to distance themselves from the pain and fear of the civilians, and conceive of them as simply possessing bare life. While their deaths would send a strong message to the Communists, the status of the civilians meant that the killings were not murder.

The Peers Commission and the court-martial of Calley reveal the denial of bios by the killers that day. During one questioning exchange, Calley discussed the indiscriminate targeting in the village: 
The ANU Undergraduate Research Journal

Q. What were they firing at?

A. At the enemy, sir.

Q. At people?

A. At the enemy, sir.

Q. They weren't human beings?

A. Yes, sir.

Q. They were human beings?

A. Yes, sir.

Q. What do you mean, you weren't discriminating?

A. I didn't discriminate between individuals in the village, sir. They were all the enemy, they were all to be destroyed (O'Brien, [1994] 1998: 667).

They had distanced themselves deliberately from the humanity of the Vietnamese in order to make sense of the War landscape, in which any one had the ability to kill them. This denial of bios was not only limited to the men on the ground. The actions of the military hierarchy to cover up the acts of the men indicate the disregard for the serious nature of the crimes, and the carelessness with which Vietnamese civilians were treated. It was only under public pressure that the fourteen men were placed on trial, and the continued apathy of the American military to this crime meant that only Calley was punished. ${ }^{12}$ Letters to Calley and surveys of the American and Australian public expressed that many thought they would act in the same manner if placed in the same position (Bourke, 1999: 194-196). The denial of bios was not only engaged in by the troops in Vietnam, but also the society from which they came. Instead of condemning the Massacre, and the participants, some Americans gave their implicit consent to the acts. A characterisation of Calley as being as much of a victim of the War as the people of Vietnam denied the violence and terror that had been experienced by the civilians in their final moments, and denied their right to be heard and respected. In the decades after the War, this image of the wounded, betrayed veteran would come to dominate the American memory of Vietnam, through informal products like films or the official places of remembrance, including the Vietnam Memorial in Washington D.C. (Burke, 2007: 172). Through this process of claiming the traumatised veteran, the nation was able to change the narrative of Vietnam from one of neo-imperialist ambitions to the exploitation

12 Encouragingly, the war crimes performed by American soldiers in the Afghan War have been taken more seriously. At the time of writing, 5 American soldiers are on trial for the 2010 murders and mutilation of 3 Afghan men, and face heavy sentences if convicted (BBC News, 2011). 
of the weak by the corrupt and powerful (Weaver, 2010: 9). This cynical process of using 'one trauma story to suppress another' has stalled the investigation and processing of American war crimes in Vietnam (Weaver, 2010: 11). Denied their bios in life, the victims of the My Lai Massacre continue to be relegated to the status of bare life: killed but not sacrificed, immortalised yet forgotten.

The My Lai Massacre exposed the undercurrents of cultural and political processes that enable soldiers to kill in war. The categories of bios and bare life divide human life by its value: that which has the full rights and citizenship of membership of a sovereign state and is accordingly precious, and that which has the barest existence, and can be killed with impunity. The shift from conventional to irregular conflicts has coincided with the nation-state being held in the bodies of the population instead of within symbolic vessels, bringing civilians into the sphere of war in an unprecedented way. To attack the state and the enemy in Vietnam was often to attack the civilians, who shared their bodies with that of enemy forces. The murky landscape of the War combined with insufficient instruction from the hierarchy left the soldiers struggling to make sense of their place in the War. In the absence of an enemy that could be killed, the soldiers attacked the civilians who represented them, and whose lives had little value. The military hierarchy and the American public ignored and consented to the Massacre through their actions, and have reclaimed the bodies of their own wounded veterans to renegotiate the narrative of the Vietnam War, a privilege of bios. The story of the My Lai Massacre is one of privilege: that of those with bios to determine the fate of those with bare life.

\section{References}

Agamben, Giorgio (1998). Homo Sacer: Sovereign Power and Bare Life. Daniel Heller-Roazen (trans.). Stanford University Press: Stanford, California.

(1999). Remnants of Auschwitz: the Witness and the Archive. Daniel Heller-Roazen (trans.) Zone Books: New York.

Australian War Memorial (n.d.a) 'Encyclopedia. Australian casualties in the Vietnam War, 1962-72' http://www.awm.gov.au/encyclopedia/vietnam/ statistics.asp No Publication Date. [Accessed 1 November 2011]

atwar/vietnam.asp No Publication Date. [Accessed 8 November 2011]

Barnett, Louise (2010). Atrocity and American Military Justice in Southeast Asia. Trial by Army. Routledge: New York. 
The ANU Undergraduate Research Journal

BBC News (2011) 'Calvin Gibbs admits taking fingers off Afghans' bodies' http:// www.bbc.co.uk/news/world-us-canada-15529751 Publication date: 31 October 2011. [Accessed 5 November 2011]

Bourke, Joanna (1999). An Intimate History of Killing. Face-to-Face Killing in Twentieth-Century Warfare. Granta Books: London.

Burke, Anthony (2007). Beyond Security, Ethics and Violence. War Against the Other. Routledge: London.

Caulfield, Michael (2007). The Vietnam Years. From the Jungle to the Australian Suburbs. Hachette Australia: Australia.

Cotkin, George (2010). Morality's Muddy Waters. Ethical Quandaries in Modern America. University of Pennsylvannia Press: Philadelphia.

Dennis, Simone and Megan Warin (2010). 'Honeyed tongues and hostile intimacy: Engaging trauma across migrant worlds' In Emotion, Space and Society. Vol. 3 (2010). pp. 50-55.

Ekberg, Sven; Dorothy Forman; Justin Nyhammer; Victor Maievskij; Martin Rossdale (1972). 'Vietnamese Policy and Pacification Programs' In Frank Browning and Dorothy Forman (1972). The Wasted Nations. Report of the International Commission of Enquiry into United States Crimes in Indochina, June 20-25, 1971. Harper and Row, Publishers: USA. pp. 104-114.

Enloe, Cynthia (2004). The Curious Feminist. University of California Press: Berkeley.

Ham, Paul (2008). Vietnam. The Australian War. Harper Collins: Australia.

Hans, Asha (2004) 'Escaping Conflict. Afghan Women in Transit' In Wenona Giles and Jennifer Hyndman (eds.) (2004). Sites of Violence: Gender and Conflict Zones. University of California Press: Berkeley. pp. 232-248.

Heinemann, Larry (1986). Paco's Story. Vintage Contemporaries: USA.

Hellman, John (1997). 'The Vietnam Film and American Memory' In Martin Evans and Ken Lunn (eds.) (1977). War and Memory in the Twentieth Century. Berg: Oxford. pp. 177-188.

Horne, Donald [1964] (1998). The Lucky Country. Penguin Group: Victoria.

Kaldor, Mary (2006). New and Old Wars $2^{\text {nd }}$ Edition. Organised Violence in a Global Era. Stanford University Press: Stanford.

Kilcullen, David (2010) Counterinsurgency. Scribe: Melbourne. 
Laclau, Ernesto (2007). 'Bare Life or Social Indeterminacy?' In Matthew Calarco and Steven DeCaroli (eds.) (2007) Giorgio Agamben. Sovereignty and Life. Stanford University Press: Stanford, California. pp. 11-22.

Lifton, Robert Jay (1973). Home From the War. Vietnam Veterans: Neither Victims nor Executioners. Simon and Schuster: New York.

McDonald, 'Country' Joe [1965]. 'I-Feel-Like-I'm-Fixin'-to-Die Rag' In Stewart O'Nan (ed.) (1998). The Vietnam Reader. The Definitive Collection of American Fiction and Nonfiction on the War. Anchor Books: New York. pp. 286-287.

O'Brien, Tim [1994]. 'In the Lake of the Woods' In Stewart O'Nan (ed.) (1998). The Vietnam Reader. The Definitive Collection of American Fiction and Nonfiction on the War. Anchor Books: New York. pp. 662-371.

Oliver, Kendrick (2006). The My Lai Massacre in American History and Memory. Manchester University Press: Manchester and New York.

Springsteen, Bruce [1984]. 'Born In The USA' In Stewart O'Nan (ed.) (1998). The Vietnam Reader. The Definitive Collection of American Fiction and Nonfiction on the War. Anchor Books: New York. pp.

Starr, Edwin [1970]. 'War' In Stewart O'Nan (ed.) (1998). The Vietnam Reader. The Definitive Collection of American Fiction and Nonfiction on the War. Anchor Books: New York. pp. 292-293.

Taussig, Michael (1984). 'Culture of Terror- Space of Death. Roger Casement's Putumayo Report and the Explanation of Torture'. In Comparative Studies in Society and History. Vol. 26, No. 3 (Jul., 1984). pp. 467-497.

Weaver, Gina Marie (2010). Ideologies of Forgetting. Rape in the Vietnam War. State University of New York Press: USA. 